\title{
UNTRADITIONAL STUDY TO CONTROL CITRUS NEMATODE TYLENCHULUS SEMIPENETRANS BY SAFETY APPLICATIONS
}

\author{
M. S. Abo-Korah \\ Economic Entomology and Agricultural Zoology Dept., Fac. of Agric., Menoufia Univ., \\ Shibin El-Kom, Egypt. \\ Received: Jun. 10 , 2020 \\ Accepted: Jun. 30,2020
}

\begin{abstract}
This study aims to use safe agents and microorganisms to control citrus nematode, Tylenchulus semipenetrans infected Naval orange to protect humans and plants from bad side effects of different chemical pesticides. The tested agents are Indole butyric acid (IBA); Entomopathogenic nematode (Steinernema feltiae) and Predacious nematode (Diplogaster Iheritieri) singly or in combination under greenhouse conditions. The results showed that, the superiority of the nematode predator, $D$. Iheritieri giving reduction percentages $(73.9 \%)$ on citrus nematode compared to entomopathogenic nematode, $S$. feltiae (50.8\%). The combined treatment (IBA+ $D$. Iheritieri) recorded the highest reduction percentages on citrus nematode $(77.4 \%)$ compared with the nematicide Tervigo (77.2\%). In addition, achieved combined treatment gave a better enhancement of Naval orange growth parameters such as plant height which increased by (84.7\%), shoot weight increased by (64.2\%), and root weight increased by (131.9\%), meanwhile, the percentage of citrus nematode females per $1 \mathrm{~g}$ roots was decreased by $(90.3 \%)$ compared to control treatment. This study recommends that, the use of certain safety methods for combating citrus nematodes can substitute of chemical control. Also, it recommends that, entomopathogenic nematodes not to be used with predatory nematodes in the same control program against citrus nematodes because there were negatively effect between each other.
\end{abstract}

Key words: Biological control; Indole butyric acid; Steinernema feltiae; Tylenchulus semipenetrans and Diplogaster Iheritieri.

\section{INTRODUCTION}

Citrus is considered one of the most important strategic fruits in the world (FAO, 2010). The best geographical location, stable Mediterranean climate and good soil fertility, as well as cheap labor, are factors that have made Egypt featured among citrus producing countries (Abd-Elgawad et al. 2016).The total cultivated area in Egypt of oranges is expected to be approximately 162,000 hectares, with an increase of $5 \%$ over last year (Omar and Tate, 2018).

Citrus nematodes are considered one of the most dangerous threats to citrus trees by infecting seedlings in nursery and trees in orchards. Adding organic fertilizers which often contaminated with many pests and diseases, as well as irrigation water, and the contaminated agricultural tools play an important role in spreading plant parasitic nematodes in agricultural lands (Abd-Elgawad et al. 2016). Tylenchulus semipenetrans causes a disease called slow degradation of citrus fruits (Abd-Elgawad , 2020). The symptoms of slow degradation which are similar to those of nutrient deficiency, dehydration, or poor root growth, leads to a gradual decrease in tree productivity (McClure and Schmitt 1996).

Indole butyric acid (IBA) is considered plant growth regulator and a good stimulant for root growth and has started to be used commercially on a larger scale to increase crop yield (Tognetti et 
al., 2010). IBA has the ability to replace the roots that the plant loses due to infested parasitic nematodes, and this is reflected in the improvement of the vegetative and fruity characteristics of the plant (Giada et al., 2017).

Entomopathogenic nematodes are widely used in biological control to eliminate insect pests, recently, some studies have been proven their ability to suppress plant parasitic nematodes (Jagdale et al., 2009). Entomopathogenic nematodes has been proven also its effective in reducing the number of plant parasitic nematodes when applied near the root zone, under greenhouse conditions (Khan et al., 2016). Studies have also demonstrated the efficacy of Steinernema spp., compared to Heterorhabditis spp., in the control of Meloidogyne incognita infected tomatoes (El-Ashry et al., 2018).

The diplogasterid has proven successful in biological control programs for plant parasitic nematodes and studies have shown that it has a high predatory efficiency (Anwar et al., 2008). Numerous experiments were conducted on the predator nematodes, Diplogaster spp. and measurement of the efficacy of predators on Meloidogyne javanica and Tylenchulus semipenetrans. It has been proven to be a strong predator with a promising future in the biological control program (Khan and Kim, 2005 ; SanchezMoreno and Ferris, 2007).

The harmful effects of chemical control on human and animal health, as well as the plants, have promoted scientists to think about alternative \& safe and harmless methods for the environment, hence the idea of the research under study.

\section{MATERIALS AND METHODS:}

\section{Source and nematode culture:}

Tylenchulus semipenetrans juveniles were obtained from the pure culture reared on Citrus aurantifolia seedlings (lemon) in the nematode laboratory of the Entomology and Zoology Department, Faculty of Agriculture, Menoufia University.

Diplogaster Iheritieri was obtained from the pure predatory nematode culture and reared under laboratory conditions. This pure culture was obtained by Prof Dr. Sanaa Haroun from nematology and biotechnology laboratory Faculty of Agriculture, Fayoum University.

Steinernema feltiae nematode was obtained kindly from a pure culture by Dr. Ahmed Azaze from Entomology and Nematology Department Agricultural Research Center, Giza, Egypt. They were cultured separately in last instar larvae of the greater wax moth Galleria mellonella L. this technique according to (Dutkey et al., 1964 and El-Ashry et al., 2018).

\section{Experimental preparation and design:}

Experiment layout was randomized complete block design. This experiment was carried out in the experimental station of the Faculty of Agriculture at Menoufia University, Egypt. The experiment was done under greenhouse conditions and each treatment consisted of (3) replicates. Three seedlings were planted Naval orange, Citrus sinensis L. (grafting on sour orange) at eighteen months old, it was planted in a plastic pot contain four kilograms of sterilized claysand mixed soil (1:1, v/v) and a size of 25 cm. Seven days later, after seedlings adaptation, $\left(1000 \mathrm{~J}_{2}\right)$ of $T$. semipenetrans per one kilogram soil were added by pipette into three holes around each seedling.

After adding $T$. semipenetrans infection, at the same time, were added at a rate (100 per pot) from predatory 
nematode $D$. Iheritieri and concentration (5000 IJs per pot) from Steinernema feltiae solely or combined (El-Ashry et al., 2018).

Indole butyric acid (IBA) the commercial product is Hormon $L \AA$ and active ingredient is indole-3-butyric acid $0.4 \%$. It was used in this experiment with concentration (2000ppm). Dose (2L/ha) and at rate $(0.2 \mathrm{ml} / \mathrm{pot})$ (Farahat et al., 2018).

Tervigo $\mathrm{TM}$ is a suspension concentrate (SC) containing 20g/L abamectin with the addition of an iron chelate $\mathrm{Fe}-\mathrm{EDDHA} 400 \mathrm{~g} / \mathrm{L}$ produced by Syngenta East Africa Ltd. This pesticide was used because, the Abamectin as an active ingredient provides effective control of nematodes, while the iron chelate is a micro fertilizer that provides crop enhancement effects especially in alkaline soils. After seven days of seedlings adaptation, Tervigo was applied as $0.4 \mathrm{ml}$ per pot as soil drench around the roots (full recommended dose 2.5I/fed.).

\section{Nematode Extraction and Counts:}

Each treatment was replicated three times according to (Southey, 1970), about (250g.) an aliquant of each composite soil samples from the rhizosphere of the growing citrus seedlings was processed for nematode extraction by mixing the soil with water and sieved through 60, 100 and 325 mesh sieves. Suspension caught on the fine sieve was modified Baermann pan extracted for $\mathbf{7 2}$ hours and the emerged nematodes were transferred to $150 \mathrm{ml}$ beaker. Nematode enumeration was determined by using Hawksley counting slide and checked by stereomicroscope.

Nematode samples were taken from the soil after $1 ; 2 ; 3 ; 4 ; 5$ and 6 months. Relying was made on the division and identification genera and species were based on morphology of the adult and larval forms, according to the description of Mai and Lyon, 1975.

At the end of the experiment, roots were washed carefully under running tap water in order to remove soil particles. A sample of one g. represent active for each composite root sample (Shafiee and Mendez, 1975). Was immediately stained with Lactophenol acid fuchsin and stored in it for not less than 24 hours and the females in roots were counted under stereomicroscope after it rinsed in water (Daykin and Hussey, 1985).

\section{Statistical analysis:}

The obtained data were subjected to analysis of variance (ANOVA) using CoStat Software, Version 6.4 (2008). The mean differences were compared by Least Significant Difference (L.S.D. 5\%)

Reduction percentages were computed according to Abbott formula (1925).

Increase or decrease \%=

Control - treatment / Control x 100.

\section{RESULTS AND DISCUSSION}

The obtained results in Table (1) show the effect of the three tested agents of this study (IBA; S. feltiae and $D$. Iheritieri) whether individually or collectively, as well as the nematicide (Tervigo) on the population density of $T$. semipenetrans juveniles that infect citrus seedlings during a period of six months, under greenhouse conditions.

Statistical analysis of the obtained data in Table (1) showed that, there are significant differences between all adopted treatments, which reduced $T$. semipenetrans population within six months, compared with control.

Results showed that, the nematode predator, $D$. Iheritieri solely has a predation capacity and higher efficiency 
more than that occurred by entomopathogenic nematode, $S$. feltiae in eliminating citrus nematode through six months, reached (379.9 ind's) and (759.8 ind's), respectively.

The combined treatment (IBA+ $D$. Iheritieri) was more efficient in reducing the population density of $T$. semipenetrans juveniles than all other treatments, including the nematicide, as it gave the lowest density of citrus nematodes during the six months (322.3 ind's), compared with the nematicide (Tervigo), which gave an average of (332.2 ind's) during the six months under greenhouse conditions.

Predatory nematodes have important and effective role in eliminating many species of parasitic nematodes (Bilgrami et al., 2005), and this is consistent with the results obtained.

Results in Table (2) showed that, when adopted each of $S$. feltiae and $D$. Iheritieri solely gave reduction percentage of $T$. semipenetrans population (50.8\%) and (73.9\%), respectively. While, when it used in a combined treatment ( $S$. feltiae $+D$. Iheritieri), the reduction percentage of citrus nematode decreased to $(59.1 \%)$, and this due to an inhabitation factor occurred in both efficiency on each other solidarity. From this result, it is not conformity to adopt this combined treatment (nematode predator + entomopathogenic nematode) in any biological control program at the same time and location, as this reduces the efficiency of each other. The obtained results are in agreement with those obtained by (El-Nasharty, 2014).

Table (1): Impact of different treatments on the population density of $T$. semipenetrans infected citrus seedlings during six months greenhouse conditions

\begin{tabular}{|c|c|c|c|c|c|c|c|}
\hline \multirow{3}{*}{ Treatments } & \multicolumn{6}{|c|}{ Aver. no. of $T$. semipenetrans juveniles/ $100 \mathrm{~g}$ soil } & \multirow{3}{*}{$\begin{array}{l}\text { Overall } \\
\text { mean }\end{array}$} \\
\hline & \multicolumn{6}{|c|}{ months post-treatments } & \\
\hline & $\begin{array}{c}\text { One } \\
\text { month }\end{array}$ & $\begin{array}{c}\text { Two } \\
\text { months }\end{array}$ & $\begin{array}{c}\text { three } \\
\text { months }\end{array}$ & $\begin{array}{c}\text { four } \\
\text { months }\end{array}$ & $\begin{array}{c}\text { five } \\
\text { months }\end{array}$ & $\begin{array}{c}\text { six } \\
\text { months }\end{array}$ & \\
\hline Indole butyric acid & $1107.0 \mathrm{~b}$ & $1184.5 \mathrm{~b}$ & $1217.0 \mathrm{~b}$ & $1301.0 \mathrm{~b}$ & $1368.5 \mathrm{~b}$ & $1428.0 \mathrm{~b}$ & $1267.7 \mathrm{~b}$ \\
\hline S. feltiae & $917.0 \mathrm{c}$ & $863.0 \mathrm{c}$ & $803.0 \mathrm{c}$ & $728.0 \mathrm{c}$ & $641.0 \mathrm{~d}$ & $607.0 \mathrm{~d}$ & $759.8 \mathrm{c}$ \\
\hline D. Iheritieri & $706.0 \mathrm{e}$ & $618.5 \mathrm{~g}$ & $493.0 \mathrm{~g}$ & $269.0 \mathrm{f}$ & $109.0 \mathrm{gh}$ & $84.0 \mathrm{~g}$ & $379.9 \mathrm{f}$ \\
\hline $\begin{array}{l}\text { Indole butyric acid } \\
+S . \text { feltiae }\end{array}$ & $909.0 \mathrm{c}$ & $854.0 \mathrm{~d}$ & $794.0 \mathrm{~d}$ & $712.0 \mathrm{~d}$ & $674.0 \mathrm{c}$ & $632.0 \mathrm{c}$ & $762.5 \mathrm{c}$ \\
\hline $\begin{array}{c}\text { Indole butyric acid } \\
+D \text {. Iheritieri }\end{array}$ & $667.0 \mathrm{f}$ & $507.0 \mathrm{i}$ & $384.0 \mathrm{i}$ & $249.0 \mathrm{~g}$ & $101.0 \mathrm{~h}$ & $62.0 \mathrm{~h}$ & $322.3 \mathrm{~h}$ \\
\hline $\begin{array}{l}\text { S. feltiae + } \\
\text { D. Iheritieri }\end{array}$ & $876.0 \mathrm{~d}$ & $718.0 \mathrm{~F}$ & $701.0 \mathrm{f}$ & $634.0 \mathrm{e}$ & $462.0 \mathrm{f}$ & $340.0 \mathrm{f}$ & $621.8 \mathrm{e}$ \\
\hline $\begin{array}{c}\text { Indole butyric acid } \\
+ \text { S. feltiae }+ \\
\text { D. Iheritieri }\end{array}$ & $909.0 \mathrm{c}$ & $831.0 \mathrm{e}$ & $719.0 \mathrm{e}$ & $639.0 \mathrm{e}$ & $503.0 \mathrm{e}$ & $410.0 \mathrm{e}$ & $668.5 \mathrm{~d}$ \\
\hline Tervigo & $631.0 \mathrm{~g}$ & $519.0 \mathrm{~h}$ & $406.0 \mathrm{~h}$ & $268.0 \mathrm{f}$ & $110.0 \mathrm{~g}$ & $59.0 \mathrm{~h}$ & $332.2 \mathrm{~g}$ \\
\hline $\begin{array}{c}\text { Control ( } T . \\
\text { semipenetrans) } \\
\text { only }\end{array}$ & $1286.0 \mathrm{a}$ & $1415.0 \mathrm{a}$ & $1562.0 \mathrm{a}$ & $1723.0 \mathrm{a}$ & $1753.0 \mathrm{a}$ & $1860.0 \mathrm{a}$ & $1599.8 \mathrm{a}$ \\
\hline LSD 5\% & 8.3 & 8.6 & 8.5 & 8.5 & 8.6 & 8.6 & 8.6 \\
\hline
\end{tabular}

means in each column followed by different letter(s) are significantly different 
Table (2): Reduction percentages of $T$. semipenetrans juveniles infected citrus seedlings as affected by several treatments along six months under greenhouse conditions

\begin{tabular}{|c|c|c|c|c|c|c|c|}
\hline \multirow{2}{*}{ Treatments } & \multicolumn{6}{|c|}{ Reduction \% } & \multirow{2}{*}{$\begin{array}{c}\text { Overal } \\
\text { mean }\end{array}$} \\
\hline & $\begin{array}{c}\text { One } \\
\text { month }\end{array}$ & $\begin{array}{c}\text { Two } \\
\text { months }\end{array}$ & $\begin{array}{c}\text { three } \\
\text { months }\end{array}$ & $\begin{array}{c}\text { four } \\
\text { months }\end{array}$ & $\begin{array}{c}\text { five } \\
\text { months }\end{array}$ & \begin{tabular}{|c|} 
six \\
months
\end{tabular} & \\
\hline $\begin{array}{c}\text { Indole butyric } \\
\text { acid }\end{array}$ & 13.9 & 16.2 & 22.1 & 24.4 & 21.9 & 23.2 & 20.3 \\
\hline S. feltiae & 28.7 & 39.0 & 48.9 & 57.7 & 63.4 & 67.3 & 50.8 \\
\hline D. Iheritieri & 45.1 & 56.3 & 68.4 & 84.4 & 93.8 & 95.5 & 73.9 \\
\hline $\begin{array}{c}\text { Indole butyric acid } \\
+ \text { S. feltiae }\end{array}$ & 29.3 & 39.7 & 49.2 & 58.7 & 61.5 & 66.0 & 50.7 \\
\hline $\begin{array}{c}\text { Indole butyric acid } \\
+D \text {. Iheritieri }\end{array}$ & 48.1 & 64.2 & 75.4 & 85.6 & 94.2 & 96.7 & 77.4 \\
\hline $\begin{array}{l}\text { S. feltiae+ } \\
\text { D. Iheritieri }\end{array}$ & 31.9 & 49.3 & 55.1 & 63.2 & 73.3 & 81.7 & 59.1 \\
\hline $\begin{array}{c}\text { Indole butyric acid } \\
+ \text { S. feltiae+ } \\
\text { D. Iheritieri }\end{array}$ & 29.3 & 41.3 & 53.9 & 62.9 & 71.3 & 77.9 & 56.1 \\
\hline Tervigo & 50.9 & 63.3 & 74.0 & 84.5 & 93.7 & 96.8 & 77.2 \\
\hline
\end{tabular}

The combined treatment $($ IBA $+D$. Iheritieri), caused maximum reduction percentage $(\mathbf{7 7 . 4 \% )}$, in citrus nematode population not only within all adopted treatments but also slightly higher than the nematicide, Tervigo (77.2\%).

There are several studies conducted to find out how the entomopathogenic nematodes infect parasitic nematodes. (Bird and Bird 1986) which reported that, the entomopathogenic nematodes are attracted to the roots of plants and a competition occurs between them and the parasitic nematodes in the root zone. (Lewis et al., 2001) recorded that, the bacteria inside the entomopathogenic nematode, lives with symbiotic entomopathogenic nematode, produce allelochemicals which has a toxic effect on the parasitic nematode. $S$. carpocapsae the symbiotic bacteria inside it, Xenorhabdus nematophilus secret enzymes P-peroxidase and Gperoxidase which stimulate the plant's systemic resistance against parasitic nematodes (Jagdale et al., 2009).
Results in Table (3) show that, the effect of different treatments on the vegetative characteristics of citrus seedlings i.e. (plant height; shoot weight and root weight) after six months of application. It is also shows the effect of the tested treatments on the number of citrus nematode females present in $1 \mathrm{~g}$ of plant root.

Statistical analysis showed that, there are significant differences between all treatments and control. The combined treatment (IBA+ $D$. Iheritieri)conformity the best treatment that improved all vegetative traits of the citrus seedlings plant height $(133.0 \mathrm{~cm})$; shoot weight $(98.7 \mathrm{~g})$ and root weight $(28.3 \mathrm{~g})$, compared with the nematicide (Tervigo) which gave $(127.0 \mathrm{~cm} ; 95.2 \mathrm{~g}$ and $24 \mathrm{~g})$; respectively. The same treatment (IBA+ $D$. Iheritieri) also gave the lowest number of citrus nematode females in a weight of $1 \mathrm{~g}$ of root and up to (20) compared to the nematicide (Tervigo) which gave (23). 
Table (3): Influence of certain treatments solely or combined on some citrus seedling vegetative characteristics and number of citrus nematode female population per $1 \mathrm{~g}$ root

\begin{tabular}{|c|c|c|c|c|}
\hline Treatments & $\begin{array}{c}\text { plant height } \\
(\mathbf{c m})\end{array}$ & $\begin{array}{c}\text { shoot weight } \\
(\mathrm{g})\end{array}$ & $\begin{array}{c}\text { root } \\
\text { weight (g) }\end{array}$ & $\begin{array}{c}\text { females per } \\
1 \mathrm{~g} \mathrm{root}\end{array}$ \\
\hline Indole butyric acid & $112.0 \mathrm{~d}$ & $83.0 \mathrm{~d}$ & $23.0 \mathrm{~b}$ & $183.0 \mathrm{~b}$ \\
\hline S. feltiae & $103.0 \mathrm{e}$ & $74.2 \mathrm{f}$ & $19.0 \mathrm{c}$ & $106.0 \mathrm{c}$ \\
\hline D. Iheritieri & $117.0 \mathrm{c}$ & $79.0 \mathrm{e}$ & $23.6 \mathrm{~b}$ & $46.0 \mathrm{~g}$ \\
\hline $\begin{array}{c}\text { Indole butyric acid + S. } \\
\text { feltiae }\end{array}$ & $109.0 \mathrm{~d}$ & $87.6 \mathrm{C}$ & $24.0 \mathrm{~b}$ & $99.0 \mathrm{~d}$ \\
\hline $\begin{array}{c}\text { Indole butyric acid + } \\
\text { D. Iheritieri }\end{array}$ & $133.0 \mathrm{a}$ & $98.7 \mathrm{a}$ & $28.3 \mathrm{a}$ & $20.0 \mathrm{~h}$ \\
\hline $\begin{array}{c}\text { S. feltiae + D. Iheritieri } \\
\text { Indole butyric acid + S. } \\
\text { feltiae + D. Iheritieri }\end{array}$ & $93.0 \mathrm{f}$ & $76.2 \mathrm{ef}$ & $19.0 \mathrm{c}$ & $74.0 \mathrm{e}$ \\
\hline \begin{tabular}{c} 
Tervigo \\
\hline $\begin{array}{c}\text { Control } \\
\text { (T. semipenetrans) only }\end{array}$
\end{tabular} & $127.0 \mathrm{~b}$ & $95.2 \mathrm{~b}$ & $24.0 \mathrm{~b}$ & $23.0 \mathrm{~h}$ \\
\hline LSD 5\% & 3.4 & $60.1 \mathrm{~g}$ & $12.2 \mathrm{~d}$ & $207.0 \mathrm{a}$ \\
\hline
\end{tabular}

means in each column followed by different letter(s) are significantly different

Data presented in Table (4) show that, all treatments leading to increments and improvements of the vegetative traits (plant height; shoot weight and root weight) and leading to a decrements in the number of citrus nematode females rate compared to the control.

The treatment of (IBA+D. Iheritieri) gave the highest percentage increasingly in vegetative traits (plant height $+84.7 \%$; shoot weight $+64.2 \%$ and root weight $+131.9 \%$ ). It also decreased the percentage of female citrus nematodes present in $(1 \mathrm{~g})$ roots to $(-90.3 \%)$ compared with control. Nematicide (Tervigo), gave an increase in the vegetative traits (plant height $+\mathbf{7 6 . 4 \%}$; shoot weight $+58.4 \%$ and root weight $+96.7 \%$ ). It gave the percentage of deficiency in the female citrus nematode reached (-88.9\%).
Indole butyric acid (IBA) leading to an increment in the percentage and improvement of vegetative traits compared with control, it has no direct effect on citrus nematodes, and this confirms that the (IBA) give the plant ability to compensate for damaged roots due to citrus nematode infection. This result is consistent with (Giada et al., 2017).

Several studies concerned with the use of entomopathogenic nematodes in the biological control of many harmful insects, as well as in the biological control of root-knot nematodes, but this study may be for the first trial was concerned with the ability of insect pathogenic nematodes to eliminate citrus nematodes. This study showed that, entomopathogenic nematodes caused a death rate of $(50.8 \%)$ on citrus nematodes 
because it has the ability to penetrate the roots of citrus seedlings and release the bacteria that live inside them symbiotic allelochemicals and that have a toxic effect on citrus nematodes. This results are in agreements with (El-Ashry et al., (2018) and Fallon et al. (2002).

Data can be summarized in succinct and succinctness as follows:

Forthright, the nematodes predatory D. Iheritieri has a predation capacity and higher efficiency solely more than that occurred by entomopathogenic nematodes in eliminating $T$. semipenetrans.

This study was interested in studying the relationship between entomopathogenic nematodes and predatory nematodes, and the results showed that each has a negative effect on the other. The possibility of predatory nematodes feeding on entomopathogenic nematodes with citrus nematodes and this reduces its efficacy in prey on citrus nematodes only. Another possibility is that predatory nematodes will be affected by the substance allelochemicals produced by bacteria that live symbiotically with entomopathogenic nematodes.

The combined treatment (IBA+ $D$. Iheritieri) success to cause maximum reduction percentage (77.4\%) in $T$. semipenetrans population, not only within all adopted treatments but also slightly higher than the death rate caused by the nematicide Tervigo (77.2\%) to take into the combined treatment is safety and not determintal while nematicide is very harmful to each of human; animals and different plants.

Major of treatments occurred in this study leading to increments and improvements of the vegetative traits and leading to decrements in the number of citrus nematode females rate compared with control.

Table (4): Increase or decrease of some growth characters of citrus seedling and number of female population per $1 \mathrm{~g}$ root as influenced by certain treatments.

\begin{tabular}{|c|c|c|c|c|}
\hline \multirow{2}{*}{ Treatments } & $\begin{array}{c}\text { plant height } \\
\mathrm{cm}\end{array}$ & $\begin{array}{c}\text { shoot weight } \\
\mathrm{g}\end{array}$ & $\begin{array}{c}\text { root } \\
\text { weight g }\end{array}$ & $\begin{array}{c}\text { females per } \\
\text { 1 g root }\end{array}$ \\
\cline { 2 - 5 } & \multicolumn{3}{|c|}{ Increase + or decrease - \% } \\
\hline Indole butyric acid & +55.5 & +38.1 & +88.5 & -11.6 \\
\hline S. feltiae & +43.1 & +23.5 & +55.7 & -48.8 \\
\hline D. Iheritieri & +62.5 & +31.4 & +93.4 & -77.8 \\
\hline $\begin{array}{c}\text { Indole butyric acid }+ \text { S. } \\
\text { feltiae }\end{array}$ & +51.4 & +45.8 & +96.7 & -52.2 \\
\hline $\begin{array}{c}\text { Indole butyric acid }+ \\
\text { D. Iheritieri }\end{array}$ & +84.7 & +64.2 & +131.9 & -90.3 \\
\hline $\begin{array}{c}\text { S. feltiae + D. Iheritieri } \\
\text { Indole butyric acid }+S . \\
\text { feltiae }+ \text { D. Iheritieri }\end{array}$ & +29.2 & +26.8 & +55.7 & -64.3 \\
\hline Tervigo & +41.7 & +41.8 & +70.5 & -69.1 \\
\hline
\end{tabular}




\section{REFERENCES}

Abbott, W.S. (1925). A method of computing the effectiveness of an insecticide. J. Econ. Entomol., 18: 265267.

Abd-Elgawad, M.M. (2020). Managing nematodes in Egyptian citrus orchards. Bulletin of the National Research Centre, 44: 1-15.

Abd-Elgawad, M.M., F.F. Koura, S.A. Montasser and M.M. Hammam (2016). Distribution and losses of Tylenchulus semipenetrans in citrus orchards on reclaimed land in Egypt. Nematology, 18:1141-1150.

Anwar, L. B, B. Christopher and G. Randy (2008). First field release of a predatory nematode, Mononchoides gaugleri (Nematoda: Diplogastrida), to control plant-parasitic nematodes. Nematology, 10 (1): 143-146.

Bilgrami, A.L., R. Gaugler and C. Brey (2005). Prey preference and feeding behavior of the diplogasterid predator Mononchoides gaugleri (Nematoda: Diplogasterida). Nematology, 7:333342.

Bird, A. and J. Bird (1986). Observations on the use of insect parasitic nematodes as a means of biological control of root-knot nematodes. Int. J. Parasitol., 16: 511-516.

Daykin, M. E. and R.S. Hussey (1985). Staining and histopathological techniques in nematology. In: Barker, K. R.; C. C. Carter and J. N. Sasser (eds), An Advanced treatise on Meloidogyne, Vo. II Methodology, pp. 39-48. North Carolina State University Graphics, Raleigh.

Dutky, S.R., J.V. Thompson and G.E. Cantwell (1964).A technique for the mass propagation of the DD-136 nematode. J. Insect Pathol., 6: 417422.

El-Ashry, R. M., A.M. Eldeeb, A.M. ElMarzoky and M. E. Mahrous (2018).
Suppression of the root-knot nematode, Meloidogyne incognita in tomato plants by application of certain entomopathogenic nematode species under greenhouse conditions Egypt. J. Agronematol., 17 (1): 25-42.

El-Nasharty, H. A., M.E. Mahrous, E.M. Mostafa and R.M. El-Ashry (2014). Predation of entomopathogenic nematodes by certain soil mite species. Zagazig J. Agric. Res., 41 (6): 1273-1283.

Fallon, D.J., H.K. Kaya, R. Gaugler and B.S. Sipes (2002). Effects of entomopathogenic nematodes on Meloidogyne javanica on tomatoes and soybeans. J. Nematol., 34: 239245.

FAO, (2010). Faostat Agriculture. http://faostat.fao.org/site/567/default.a spx\#ancor, accessed on 30 Nov 2010.

Farahat, A. A., A. A. Al-Sayed, M. Adam and F. D. Shaimaa (2018). Comparative Efficacy of biotic and abiotic agrocommercial products against Rotylenchulus reniformis under field conditions. Egypt. J. Agronematol., 17 (1): 77- 93.

Giada, E., M. Roberta, V. Francesco, L. Silvia, F. R. Pio and L. W. Sheridan (2017). Nematicidal efficacy of new abamectin-based products used alone and in combination with indolebutyric acid against the root-knot nematode Meloidogyne incognita. J. of Zoology, (100): 95-101.

Jagdale, G.B., S. Kamoun and P.S. Grewal (2009). Entomopathogenic nematodes induce components of systemic resistance in plants: Biochemical and molecular evidence. Biol. Contr. 51:102-109.

Khan, Z. and Y.H. Kim (2005). The predatory nematode, Mononchoides fortidens (Nematoda: Diplogasterida), suppresses the root-knot nematode, 
Meloidogyne arenaria, in potted field soil. Biol. Control, 35:78-82.

Khan, S.A., N. Javed, M. Kamran, H. Abbas, A. Safdar and I. Haq (2016). Management of Meloidogyne incognita Race 1 through the use of entomopathogenic nematodes in tomato. Pakistan J. Zool., 48 (3): 763768.

Lewis, E.E., P.S. Grewal and S. Sardanelli (2001). Interactions between the Steinernema feltiae- Xenorhabdus bovieniiinsect pathogen complex and the root-knot nematode Meloidogyne incognita. Biol. Contr. 21:55-62.

Mai, W.F. and H. H. Lyon (1975). Plant Parasitic Nematodes: A Pictorial Key to Genera (Comstock Books) Publisher: Peter G. Mullin, Cornell University Press; 5th ed., 277 pp.

McClure, M.A. and M.E. Schmitt (1996). Control of citrus nematode, Tylenchulus semipenetrans, with cadusafos. J. Nematol. 28:624-628.

Omar, S. and B. Tate (2018). Egypt: Citrus Annual. Gain Report Number: EG
18031, USDA Foreign Agricultural Service, $10 \mathrm{p}$.

Sanchez-Moreno, S. and H. Ferris (2007). Suppressive service of the soil food web: Effects of environmental management. Agr. Ecosyst. Environ. 119:75-87.

Shafiee, M. F. and J. M. Mendez (1975). Seasonal fluctuations in Radopholus similis on three varieties of Musa sp. Ciencias Universided de la Habana, Serie II, Sanidad Vegetal.12, 12pp.

Southey, J. F. (1970). Laboratory methods for work with plant and soil nematodes. Ministry of Agriculture, Fishers and Food. Technical Bulletin 2: $5^{\text {th }}$ ed., 148 pp.

Tognetti, V.B., A.O. Van, K. Morreel, B.K. Vanden, C.B. Vande, I. Declercq, S. Chiwocha, R. Fenske, E. Prinsen, W. Boerjan, B. Genty, K.A. Stubbs, D. Inz and V. F. Breusegem (2010). Perturbation of indole-3-butyric acid homeostasis by the UDPglucosyltransferase UGT74E2 modulates Arabidopsis architecture and water stress tolerance. Plant Cell, 22 (8): 60-79. 
Tylenchulus semipenetrans دراسة غير تقليدية لمكافحة نيماتودا الموالح

\section{بواسطة تطبيقات آمنة}

\section{محمد سعيد أبوقورة}

قسم الحشرات الاقتصادية والحيوان الزراعى - كلية الزراعة - جامعة المنوفية - مصر

الملغص العربي

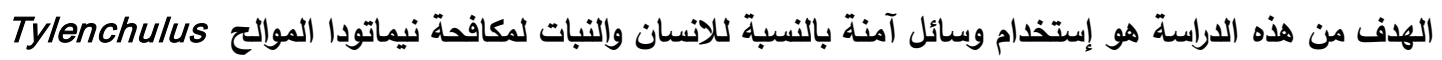

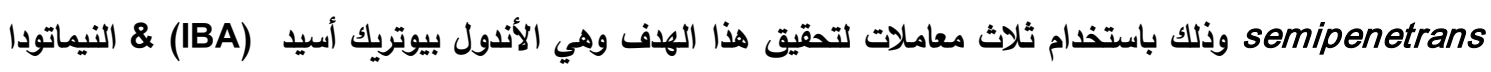

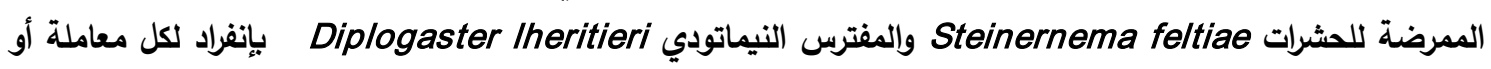
بالخلط بينهما وذلك تحت ظروف الصوبة.

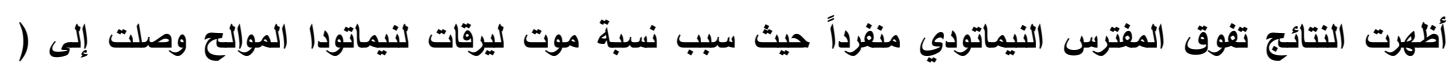

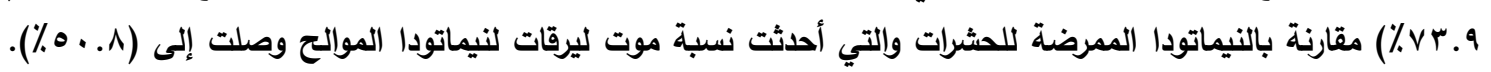

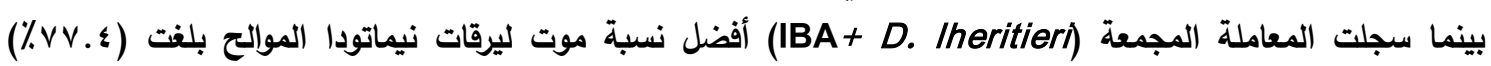

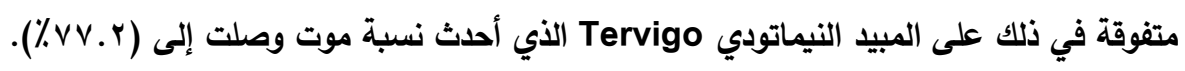

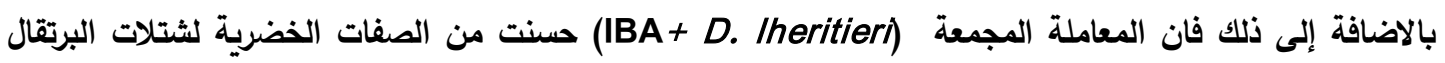

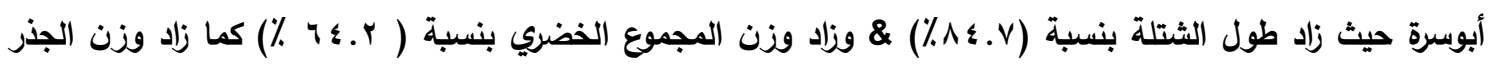

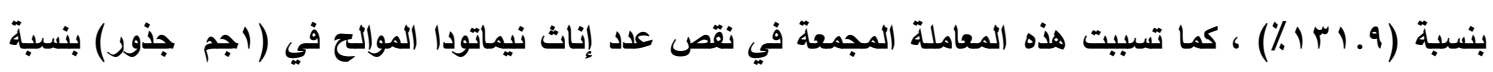

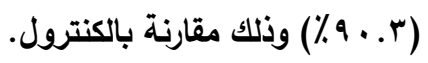

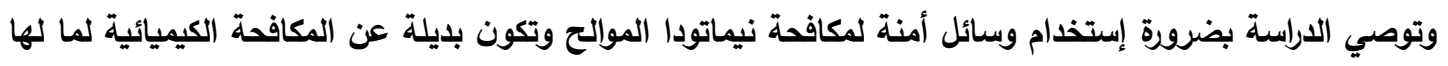

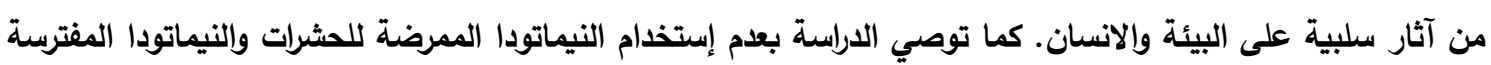
في برنامج مكافحة واحد لأن إستخدامهم في نفس ذات الوقان الوقت والمكان يؤثر كل منهما على الأخر تأثيرا سلبيا. 
